\title{
Response of Growing Rabbits to Diets Containing Different Levels of Protein and Radish (Raphanus sativus L) Seeds
}

\author{
A. A. Abedo \\ Animal Production Department, National Research Centre, Dokki, Giza, Egypt \\ Tel: 20-112-373-380Ｅ-mail: abedoaa@hahoo.com \\ F. A. F. Ali \\ Animal Production Department, National Research Centre, Dokki, Giza, Egypt \\ Tel: 20-101-461-585 E-mail: mf_ahmed@live.com \\ H. A. A. Omer \\ Animal Production Department, National Research Centre, Dokki, Giza, Egypt \\ Tel: 20-114-089-312 E-mail: hamedomer2000@yahoo.com \\ Sh. A. M. Ibrahim (Corresponding author). \\ Animal Production Department, National Research Centre, Dokki, Giza, Egypt \\ Tel: 20-101-694-188 E-mail: shawki_nrc@yahoo.com
}

$\begin{array}{lr}\text { Received: April 29, } 2011 & \text { Accepted: May 27, } 2011 \quad \text { Online Published: December 29, } 2011 \\ \text { doi:10.5539/jas.v4n3p281 } & \text { URL: http://dx.doi.org/10.5539/jas.v4n3p281 }\end{array}$

\begin{abstract}
This work aimed to study the effect of two different levels of ration protein supplemented with Radish (Raphanus sativus L) seeds (RS). Rabbits were classified into four equal groups (G1-G4). The ${ }^{s t}$ and $3^{\text {rd }}$ groups received basal ration with $100 \%$ and $90 \%$ of protein requirement level and served as first and second control respectively. The $2^{\text {nd }}$ and the $4^{\text {th }}$ groups received basal ration with 100 and $90 \%$ of protein supplemented with RS at the level $1.5 \%$, respectively.

The $90 \%$ of protein level significantly $(\mathrm{P}<0.05)$ increased the DM, OM, CP, CF and EE digestibility and TDN value as well as significantly $(\mathrm{P}<0.05)$ decreased the digestible $\mathrm{CP}$ in comparison with the $100 \%$ requirements. The $90 \%$ of protein level significantly $(\mathrm{P}<0.05)$ increased the TDN intake. The $100 \%$ of protein level significantly $(\mathrm{P}<0.05)$ improved the feed conversion ( $\mathrm{g}$ intake $/ \mathrm{g}$ gain) of DM, TDN and DE $(\mathrm{kcal} / \mathrm{h} / \mathrm{d})$. The $90 \%$ of protein level insignificantly $(\mathrm{P}>0.05)$ improved the final weight, total body weight gain, ADG (g), feed intake as DM, DCP, DCP (g/day) and DE ( $\mathrm{kcal} / \mathrm{h} / \mathrm{d})$ and feed conversion (g intake $/ \mathrm{g}$ gain) of CP in comparison with the $100 \%$ of protein requirements.

Radish seeds $(\mathrm{RS})$ at $1.5 \%$ level significantly $(\mathrm{P}<0.05)$ increased all nutrient digestibility coefficients and nutritive values compared to the control diet. There were significant $(\mathrm{P}<0.05)$ interactions between the protein and RS levels on all nutrient digestibility coefficients (DM, OM, CP, CF, EE and NFE) and nutritive values of TDN and DCP. The $90 \%$ of protein level $+1.5 \%$ (RS) showed the best digestion coefficients of DM, OM, CP, CF, EE and NFE and TDN value. The $100 \%$ of protein level $+1.5 \%$ Radish seeds $\left(\mathrm{G}_{2}\right)$ showed the highest value of DCP. Supplementation Radish seeds at $1.5 \%$ level significantly $(\mathrm{P}<0.05)$ improved feed intake as DCP and TDN (g/day) while, it significantly $(\mathrm{P}<0.05)$ decreased feed conversion ( $\mathrm{g}$ intake $/ \mathrm{g}$ gain) of TDN. Adding Radish seeds at $1.5 \%$ level insignificantly $(\mathrm{P}>0.05)$ increased the final weight, total body weight gain, average daily gain (ADG); feed intake as DM, CP (g/day) and DE (kcal/h/d) and feed conversion ( $\mathrm{g}$ intake $/ \mathrm{g}$ gain) of $\mathrm{DM}, \mathrm{CP}$ and DE $(\mathrm{kcal} / \mathrm{h} / \mathrm{d})$ compared to the control diet. The $90 \%$ of protein requirement with supplementation Radish seeds at $1.5 \%$ level recorded the best values of final weight, total body weight gain, average daily gain, feed intake (g/h/day) of DM, DCP, TDN and DE and feed conversion feed conversion of DM, CP and TDN ( $g$ intake/g gain) and DE (Kcal intake /g gain). There were interactions between protein and supplementation levels on DM, DP, TDN and DE intakes and feed conversion (g intake/g gain) of DM, CP, TDN and DE. There were significant $(\mathrm{P}<0.05)$ interactions between protein and supplementation levels on carcass characteristics such as
\end{abstract}


digestive tract; edible offal's weight (head and testes, weight and \% of SW) and dressing percentages expressed as CW1/ SW and DM of the 9,10 and $11^{\text {th }}$ ribs. Rabbits fed on diet containing the $90 \%$ of protein requirements with $1.5 \%$ (RS) showed the highest values of net revenue, economical efficiency and relative economic efficiency, Supplementation of radish seeds in rabbit diets improved all nutrient digestibility, growth performance, dressing percentages and economical efficiency indicating that radish seeds can be used as growth promoter for improving the utilization of low protein in rabbit diets.

Keywords: Radish seeds, Rabbits, Growth performance, Digestibility, Carcass characteristics, Economic evaluation

\section{Introduction}

Radish (figle) used in this study is the dried seeds of Raphanus sativus $L$ (RS), belonging to the Brassicaceae family. Recently, it has been found that some medicinal plants have growth enhancing properties. Some medicinal plants can be used as natural additives, tonic and restoratives in animal and poultry diets (Boulos, 1983), or to improve growth performance, immunity and viability (El-Hindawy et al., 1996). The found inhibitors with their characteristic profiles in radish be useful in biochemical and pathophysiological on granulocyte proteinases and enzymes of the coagulation and fibrinolytic pathways (Ghayur et al., 2005). Raphanus sativus $L$ has laxative and gastrointestinal and uterine tone modulatory activities (Zhang et al., 2010). Raphanus sativus $L$ may be used for the prevention and treatment of neuro degenerative diseases (Bae et al., 2010). Raphanus sativus $L$ provides protection by strengthening the antioxidants like glutathione and catalase (Chaturvedi, 2008). Raphanus sativus $L$ extracts rich in many antioxidant compounds, were safe and successfully countered oxidative stress and provided protection against the toxicity (Salah-Abbès et al., 2009). The antioxidant properties of Raphanus sativus $L$ via induced bile flow in rats (Barillari et al., 2006). Raphanus sativus $L$ exerts potential chemo preventive efficacy and induces apoptosis in cancer cell lines through modulation of genes involved in apoptotic signaling pathway (Beevi et al., 2010). Radish extract may partially prevent hepatotoxicity, possibly by indirectly acting as an antioxidant by improving the detoxification system (Baek et al., 2008). Radish extract contains several compounds that are able to inhibit mycotoxin toxicity (Ben Salah-Abbès et al., 2008).

Low dietary protein requirements may cause imbalance in the body metabolism and growth performance. The hypothesis that sulfur compounds has ability to repair the tissue defection protein of the cells (Georgievskii et al., 1982). Sulfur is indispensable for synthesis of certain compounds-mainly sulphated mucopolysaccharides in the body (Georgievskii et al., 1982). The requirements of sulfur containing amino acids by monogastric animals is $3-4 \%$ of the feed protein, and the requirement for sulfur is $0.6-0.8 \%$ of the protein (Georgievskii et al., 1982). There are antifungal proteins, isolated from Radish seed or leaves, which consist of 50 or 51 amino acids and belong to the plant defensin family of proteins (Schaaper et al., 2001). The complete primary structure of Japanese radish component was established by sequencing of the whole protein and of peptides generated by protease digestion (Obata et al., 1995). Sulfur-radish extract may prevent hepatotoxicity, possibly by indirectly acting as an antioxidant by improving the detoxification system (Baek et al., 2008).

This work aimed to evaluate the efficacy of Radish (Raphanus sativus $L$ ) seeds as feed additive to improve the utilization of low protein rabbit diet as well as growth performance.

\section{Materials and Methods}

\subsection{Experimental animals and feeds}

A total number of 36 male New Zealand White rabbits aged 5 weeks with an average body weight of $745.5 \pm$ $20.62 \mathrm{~g}$, were divided into four equal groups. The basal experimental diet was formulated and pelleted to cover the nutrient requirements of rabbits as a basal diet according to (NRC, 1977) as shown in (Table 1). Radish (Raphanus sativus $L$ ) seeds were used as feed additive. The feeding period was extended for 56 days, and the experimental groups were classified as follow:

Group 1 basal diet with $100 \%$ protein requirement and served as control (G1),

Group 2 basal diet with $100 \%$ protein requirement $+1.5 \%$ radish seeds $(\mathrm{G} 2)$,

Group 3 basal diet with $90 \%$ protein requirement and served as control (G3) and

Group 4 basal diet with $90 \%$ protein requirement $+1.5 \%$ radish seeds (G4).

Rabbits were individually housed in galvanized wire cages $(30 \times 35 \times 40 \mathrm{~cm})$. Stainless steel nipples for drinking and feeders allowing recording of individual feed intake for each rabbit were supplied for each cage. Feed and water were offered ad libitum. Rabbits of all groups were kept under the same managemental conditions and were individually weighed. Feed consumption was individually recorded weekly during the experimental period. 


\subsection{Digestibility trials}

All rabbits were used in digestibility trials over period of 7 days to determine the nutrient digestibility coefficients and nutritive values of the tested diets.. Feed intake of experimental rations and weight of feces were recorded daily. Representative samples of feces was were dried at $60^{\circ} \mathrm{C}$ for $48 \mathrm{hrs}$, ground and stored for chemical analysis later.

\subsection{Carcass traits}

Six representative rabbits from each treatment were randomly chosen and fasted for 12 hours before slaughtering according to Blasco et al. (1993) to determine the carcass measurements. Edible offal's included head, liver, heart, testes and kidneys. These were removed and individually weighed. Full and empty weights of digestive tract were recorded and digestive tract contents were calculated by differences between full and empty digestive tract. Weights of edible and external offal's were calculated as percentages of slaughter weight (SW). Hot carcass was weighed and divided into fore, middle and hind parts. The 9,10 and $11^{\text {th }}$ ribs were frozen in polyethylene bags for chemical analysis later. The best ribs of samples were dried at $60 \mathrm{C}^{\circ}$ for $24 \mathrm{hrs}$. The air-dried samples were analyzed for DM, EE and ash according to the A.O.A.C. (2000) methods, while CP percentage was determined by difference as recommended by O'Mara et al. (1979).

\subsection{Analysis procedures}

Chemical analysis of experimental rations and feces were analyzed according to A.O.A.C (2000) methods. Neutral detergent fiber (NDF), acid detergent fiber (ADF) and acid detergent lignin (ADL)\} were also determined in the experimental rations according to Goering and Van Soest (1970). Hemicellulose was calculated as the difference between NDF and ADF, while cellulose was calculated as the difference between $\mathrm{ADF}$ and ADL.

Gross energy (mega calories per kilogram DM) was calculated according to Blaxter (1968), where, each g of crude protein $(\mathrm{CP})=5.65 \mathrm{kcal}$, each $\mathrm{g}$ of ether extract $(\mathrm{EE})=9.40 \mathrm{kcal}$, and each $\mathrm{g}$ crude fiber $(\mathrm{CF})$ and nitrogen-free extract $(\mathrm{NFE})=4.15 \mathrm{kcal}$.

Digestible energy (DE) was calculated according to Fekete and Gippert (1986) using the following equation: DE $(\mathrm{kcal} / \mathrm{kg} \mathrm{DM})=4253-32.6(\mathrm{CF} \%)-144.4($ total ash) .

Non fibrous carbohydrates (NFC) was calculated according to Calsamiglia et al. (1995) using the following equation: $\mathrm{NFC}=100-\{\mathrm{CP}+\mathrm{EE}+\mathrm{Ash}+\mathrm{NDF}\}$.

Diets were offered pelleted and the diameter of the pellets was $4 \mathrm{~mm}$.

\subsection{Economical evaluation}

Economical efficiency of experimental diets was calculated according to the local market price of ingredients and rabbit live body weight as following:

Net revenue $=$ total revenue - total feed cost.

Economical efficiency $(\%)=($ net revenue/ total feed cost $)-\mathrm{x} 100$

\subsection{Statistical analysis}

Collected data were subjected to statistical analysis as two factors-factorial analysis of variance using the general linear model procedure of SPSS (1998). Duncan's Multiple Range Test (1955) was used to separate means when the dietary treatment effect was significant.

\section{Results and discussion}

\subsection{Chemical analysis and cell wall constituents of the experimental diets}

Data of Table (2) showed that dietary treatment was isocaloric but differed in protein contents. Protein contents for the tested rations $\left(\mathrm{G}_{1}-\mathrm{G}_{4}\right)$ was $16.10,16.05,14.52$ and $14.49 \%$, respectively. The $90 \%$ of protein containing diet showed slight decrease in cell wall constituents (NDF, ADF, ADL and hemicellulose contents). On the other hand cellulose content of the experimental rations showed approximately the same trend (Table 2). These variations were related to differ in ingredients that used in ration formulations, also to study the effect of decreasing protein level on rabbit performance. These data may suggest that alterations in metabolism involved in adaptation to a diet high in hemicellulose and pectin content of radish indicating an increased propensity for oxidative metabolism occurred in the intestine, similar result observed by Nishimura et al. (2000).

\subsection{Nutrient digestibility and nutritive values of the experimental diets}

Rabbits fed on diets containing $90 \%$ protein level showed significant improvement in nutrient digestibilities $(\mathrm{P}<0.05) \mathrm{DM}, \mathrm{OM}, \mathrm{CP}, \mathrm{CF}$ and EE digestibility and TDN value (Table 3$)$. Increase in NFE digestibility was insignificant $(\mathrm{P}>0.05)$, however, digestible crude protein was significantly decreased $(\mathrm{P}<0.05)$ in comparison 
with $100 \%$ energy requirements. When CP content is low the CF should be high and therefore the digestive efficiency in the small intestine appeared higher and must lead to improve the properties of digestion (Milis and Liamadis, 2008).

Inclusion of Radish seeds at $1.5 \%$ in rabbit diets significantly $(\mathrm{P}<0.05)$ increased all nutrient digestibility coefficients and nutritive values compared to the control diets (Table 3 ).

There were significant $(\mathrm{P}<0.05)$ interactions between the protein and RS levels on all nutrient digestibility coefficients (DM, OM, CP, CF, EE and NFE) and nutritive values of TDN and DCP (Table 4).

Rabbits which received $90 \%$ of protein requirement $+1.5 \%$ Radish seeds $\left(\mathrm{G}_{4}\right)$ showed the best digestion coefficients of DM, OM, CP, CF, EE and NFE and TDN value (Table 4). On the other hand rabbits that received $100 \%$ of protein requirement $+1.5 \%$ Radish seeds $\left(\mathrm{G}_{2}\right)$ showed the highest value of DCP. These results may be due to the improvement in the epithelial lining, the number of enterocytes as well as increased the numbers of goblet cells that secrete mucin in gut in responses to Radish seeds, as has been observed previously by Sipos et al. (2002).

\subsection{Growth performance of the experimental groups}

Data of Table (5) indicate that feeding rabbits on $90 \%$ of protein requirements did not have any significant effect on improvement of the final weight, total body weight gain, ADG $(\mathrm{g})$; feed intake as DM, DCP, DCP (g/day) and $\mathrm{DE}(\mathrm{kcal} / \mathrm{head} / \mathrm{day})$ and feed conversion ( $\mathrm{g}$ intake/ $\mathrm{g}$ gain) of $\mathrm{CP}$ in comparison with $100 \%$ of protein requirements. However, $90 \%$ of protein requirements significantly $(\mathrm{P}<0.05)$ increased TDN intake. On the other hand, rabbits which received $100 \%$ of protein requirements showed significantly $(\mathrm{P}<0.05)$ improved feed conversion (g intake/g gain) of DM, TDN and DE (kcal/head/day). The insignificant improved at the lesser protein level indicated that decreasing the dietary protein level be against the level of fiber which leads to improve the properties of digestion of rabbits, similar results obtained in rabbit by Gidenne (1992) who reported that adaptation to a high-fiber diet resulted in a higher digestive volume for colon and caecum, related to an improved degradation of cell wall. Furthermore, digestive efficiency in the small intestine appeared higher for rabbits adapted to a high-fibre diet than that for rabbits initially fed on a low-fibre diet, similar results noticed by Rigó (1982).

Though the inclusion of RS at $1.5 \%$ in rabbit diet increased the marketing weight, total body weight gain and average daily gain by $5.55 \% 7.81 \%$ and $7.80 \%$, respectively compared to the control group, the increase was not significant $(\mathrm{P}>0.05)$. However, the inclusion $1.5 \%$ Radish seeds significantly improved $(\mathrm{P}<0.05)$ feed intake as DCP and TDN $(\mathrm{g} /$ day) while it significantly $(\mathrm{P}<0.05)$ decreased feed conversion $(\mathrm{g}$ intake $/ \mathrm{g}$ gain) of TDN. These results may be due to the lactic acid bacterial strain, which is derived from Raphanus sativus L. fermentation, holds great promise for use in probiotics and as a food additive since it can reduce the number of some pathogenic bacteria through production of lactic acids, similar results obtained by Chon and Choi (2010).

Data of Table (6) revealed that there were no interactions between protein and supplementation levels (PxS) on final weight, total body weight gain, average daily gain (ADG) and $\mathrm{CP}$ intake ( $\mathrm{g} /$ head/day) and feed conversion (g intake/g gain) of DCP. While, there were interactions between protein and supplementation levels (PxS) on DM, DP, TDN and DE intakes and feed conversion (g intake/g gain) of DM, CP, TDN and DE. These interactions results may be due to that Raphanus sativus $L$ has mediated partially gastrointestinal effects partially through cholinergic receptors in rabbit tissues and providing a scientific basis for its use in gut, as noticed by Ghayur and Gilani (2005).

Rabbits received $90 \%$ of protein requirement and $1.5 \%$ supplementation of Radish seeds $\left(\mathrm{G}_{4}\right)$ recorded the best values of final weight, total body weight gain, average daily gain, feed intake $(\mathrm{g} / \mathrm{h} / \mathrm{day})$ of $\mathrm{DM}, \mathrm{DCP}, \mathrm{TDN}$ and $\mathrm{DE}$ and feed conversion feed conversion of DM, CP and TDN (g intake/g gain) and DE (Kcal intake/g gain). These results in agreement with those found by Jung et al. (2000). Who recorded that RS stimulates gastrointestinal motility through activation of muscarinic pathways via induced ileal contraction It may be due to the antibacterial activity of Radish against food borne and resistant pathogens, such as Bacillus subtilis, Staphylococcus aureus, Staphylococcus epidermidis, Enterococcus faecalis, Salmonella typhimurium, Enterobacter aerogenes, Enterobacter cloacae, and Escherichia coli, as reported by Beevi et al. (2009).

\subsection{Carcass characteristics of the experimental groups}

Main effects of protein and supplementation levels on dressing percentages, carcass cuts and chemical analysis of the 9,10 an $11^{\text {th }}$ ribs of the experimental groups are presented in Table (7). The results indicate that that protein or supplementation levels of Radish seeds had no significant effect $(\mathrm{P}>0.05)$ on inedible offal's (weight and \% of SW); digestive tract empty body weight (EBW); edible offal's (head, liver, heart, kidneys and testes (weight and \% of SW); carcass weight; dressing percentages; carcass cuts and chemical analysis of the 9,10 and $11^{\text {th }}$ ribs although protein level or Radish seeds in rabbit diets slightly decreased dressing percentages. These 
results in agreement with those obtained by Satoh et al (1993) who noted that the hypocholesterolemic action of radish may have been due to the inhibition of intestinal absorption of both cholesterol and bile acids.

There were significant $(\mathrm{P}<0.05)$ interactions between protein and supplementation levels $(\mathrm{PxS})$ on digestive tract; edible offal's (head and testes, weight and $\%$ of $\mathrm{SW}$ ); dressing percentages expressed as $\mathrm{CW}_{1} / \mathrm{SW}$ and $\mathrm{DM}$ of the 9,10 and $11^{\text {th }}$ ribs (Table 8), while there were no interaction between protein and supplementation levels (PxS) on the other carcass parameters. Rabbits which received $90 \%$ protein and $1.5 \%$ supplementation of radish seeds $\left(\mathrm{G}_{4}\right)$ recorded the best value of carcass weight. These results in agreement with those noticed by Kwon et al. (2009) who indicated that the methylisogermabullone purified from radish differently regulates the spontaneous contractility (tone and/or amplitude) of gastrointestinal segments according to the region of gut and orientation of smooth muscles, and these contractile responses of gastrointestinal tracts by activation of acetylcholinergic receptors.

\subsection{Economical evaluation}

The economical efficiency of dietary treatments is presented in Table (9). The profitability of using Radish seeds as supplementation depends on upon the price of tested diets and the growth performance of rabbits fed these diets. Costing of one kg feed, (LE) decreased by $9.10 \%\left(\mathrm{G}_{3}\right)$ and $6.49 \%\left(\mathrm{G}_{4}\right)$ compared to control diet $\left(\mathrm{G}_{1}\right)$. Rabbits fed diet containing $90 \%$ protein requirements with $1.5 \%$ Radish seeds $\left(\mathrm{G}_{4}\right)$ showed the highest values of net revenue (26.64 LE), economical efficiency (0.9064) and relative economic efficiency $(111.6 \%)$, with the lowest value of feed cost/ kg live body weight $(4.08 \mathrm{LE})$. These results are due to the high weight of carcass and growth performance values that reflect the high nutritional value of radish seeds. Similar results in using golden mustard seeds were reported by (Chow et al., 2010). These results are in agreement with those obtained by Ibrahim et al. (2009) when rabbits were fed on two different levels of energy supplemented with Artemisia herba-alba, Matricaria recutita L. and Chrysanthemum coronarium as herbs mixture.

\section{Conclusion}

Dietary $90 \%$ of protein requirements with $1.5 \%$ radish seeds showed the highest value of net revenue, economical efficiency and relative economic efficiency, the lower value of feed cost/ kg live body weight (LE) as well as the best parameters of growth performance and digestibility coefficients. Our data suggest that radish seeds can be considered as an effective growth promoter for improving the utilization of low protein diet.

\section{References}

A.O.A.C. (2000). Official Methods of Analysis, $17^{\text {th }}$ ed. Association of Official Analytical.

Bae, N., Ahn, T., Chung, S., Oh, MS., Ko, H., Oh, H., Park, G. \& Yang, HO. (2010). The neuroprotective effect of modified Yeoldahanso-tang via autophagy enhancement in models of Parkinson's disease. J Ethnopharmacol, 134(2):313-322. http://dx.doi.org/10.1016/j.jep.2010.12.016

Baek, SH., Park, M., Suh, JH. \& Choi, HS. (2008). Protective effects of an extract of young radish (Raphanus sativus $L$ ) cultivated with sulfur (sulfur-radish extract) and of sulforaphane on carbon tetrachloride-induced hepatotoxicity. Biosci Biotechnol Biochem., 72(5): 1176-1182. http://dx.doi.org/10.1271/bbb.70545

Barillari, J., Cervellati, R., Costa, S., Guerra, MC., Speroni, E. \& Utan, A. Iori. (2006). Antioxidant and choleretic properties of Raphanus sativus L. sprout (Kaiware Daikon) extract. 1. J Agric Food Chem., 54(26): 9773-9778. http://dx.doi.org/10.1021/jf061838u

Beevi, SS., Mangamoori, LN., Dhand, V. \& Ramakrishna, DS. (2009). Isothiocyanate profile and selective antibacterial activity of root, stem, and leaf extracts derived from Raphanus sativus L. Foodborne Pathog. Dis., 6 (1): 129-136. http://dx.doi.org/10.1089/fpd.2008.0166

Beevi, SS., Mangamoori, LN., Subathra, M. \& Edula, JR. (2010). Hexane extract of Raphanus sativus L. roots inhibits cell proliferation and induces apoptosis in human cancer cells by modulating genes related to apoptotic pathway. Plant Foods Hum Nutr., 65 (3): 200-209. http://dx.doi.org/10.1007/s11130-010-0178-0

Ben Salah-Abbès, J., Abbès, S., Houas, Z., Abdel-Wahhab, MA. \& Oueslati, R. (2008). Zearalenone induces immunotoxicity in mice: possible protective effects of radish extract (Raphanus sativus). J Pharm Pharmacol, 60 (6): 761-770. http://dx.doi.org/10.1211/jpp.60.6.0012

Blasco, A., Quhayaun, J. \& Masoscro, G. (1993). Hormonization of criteria and terminology in rabbit meat research. World Rabbits Sciences, 1: 3-10.

Blaxter, K.L. (1968). The energy metabolism of ruminants. $2^{\text {nd }}$ ed. Charles Thomas Publisher. Spring field. Illinois, U.S.A.

Boulos, I. (1983). Medicinal plants of North Africa reference Publication. Inc. proc., $2^{\text {nd }}$ Con. Fac. Vit. Me. Cairo. Univ., Cairo, Egypt (1992). 
Calsamiglia, S., Stem, M.D. \& Frinkins, J.L. (1995). Effects of protein source on nitrogen metabolism in continuous culture and intestinal digestion in vitro. J. Anim. Sci., 73:1819.

Chaturvedi, P. (2008). Inhibitory response of raphanus sativus on lipid peroxidation in albino rats. 1: Evid Based Complement Alternat Med., 5 (1): 55-59. http://dx.doi.org/10.1093/ecam/nel077

Chon, H. \& Choi, B. (2010). The effects of a vegetable-derived probiotic lactic acid bacterium on the immune response. Microbiol Immunol, 54 (4): 228-236. http://dx.doi.org/10.1111/j.1348-0421.2010.00202.x

Chow, J., Klein, EY. \& Laxminarayan, R. (2010). Cost-effectiveness of "golden mustard" for treating vitamin A deficiency in India. PLOS One, 5 (8): 12046. http://dx.doi.org/10.1371/journal.pone.0012046

Duncan, D.B. (1955). Multiple Rang and Multiple F-Test Biometrics, 11: 1- 42. http://dx.doi.org/10.2307/3001478

El-Hindawy, M.M., Tawfeek, M.L., \& Osman, S.H. (1996). Effect of some biological feed additives for different periods on performance of broiler chick. Zagazig J. Agri. Res., 23: 773-783.

Fekete, S. \& Gippert, T. (1986). Digestibility and nutritive value of nineteen important feedstuffs for rabbits. $J$. Appli. Rabbit Res., 9 (3): 103-108.

Georgievskii, VI., Annenkov, BN. \& Samokhin, VI. (1982). Studies in the agriculyural and food sciences “Mineral Nutrition of Animals" USSR.Butterworths.

Ghayur, MN. \& Gilani, AH. (2005). Gastrointestinal stimulatory and uterotonic activities of dietary radish leaves extract are mediated through multiple pathways. Phytother Res., 19 (9): 750-755. http://dx.doi.org/10.1002/ptr.1753

Ghayur, MN., Gilani, AH. \& Houghton, PJ. (2005). Species differences in the gut stimulatory effects of radish seeds. J. Pharm Pharmacol., 57 (11): 1493-1501. http://dx.doi.org/10.1211/jpp.57.11.0016

Gidenne, T. (1992). Effect of fiber level, particle size and adaptation period on digestibility and rate of passage as measured at the ileum and in the feces in the adult rabbit. Br. J. Nutr., 67 (1): 133-146. http://dx.doi.org/10.1079/BJN19920015

Goering, H. K. \& Van Soest, P.J (1970). Forge fiber analysis (apparatus, reagents, procedure and some applications). Agric. Hand book 379, USDA, Washington, and DC., USA.

Ibrahim, Sh. A. M., Abedo, A.A., Omer, H.A.A. \& Ali, F.A.F. (2009). Response of growing New Zealand White rabbits to diets containing different levels of energy and mixture of some medical plants. World Journal of Agricultural Science, 5 (5) 544-551.

Jung, KY., Choo, YK., Kim, HM. \& Choi, BK. (2000). Radish extract stimulates motility of the intestine via the muscarinic receptors. J. Pharm Pharmacol., 52 (8): 1031-1036. http://dx.doi.org/10.1211/0022357001774769

Kwon, OD., Jeung, SI., Lee, S., Choi, YS., Choi, BK. \& Jung, KY. (2009). Different stimulatory effects of methylisogermabullone on the spontaneous contractility of rat gastrointestinal segments. Arch Pharm Res., 32 (11): 1613-1620. http://dx.doi.org/10.1007/s12272-009-2115-z

Milis, Ch. \& Liamadis, D. (2008). Nutrient digestibility and energy value of sheep rations differing in protein level, main protein source and non-forage fiber source. J Anim. Physiol. Anim. Nutr. (Berl)., 92 (1): 44-52.

N.R.C. (1977). National Research Council. Nutrient requirements of rabbits, National Academy of Science, Washington, D.C, USA.

Nishimura, N., Taniguchi, Y. \& Kiriyama, S. (2000). Plasma cholesterol-lowering effect on rats of dietary fiber extracted from immature plants. Biosci Biotechnol Biochem., 64 (12): 2543-2551. http://dx.doi.org/10.1271/bbb.64.2543

Obata, S., Nishimura, M., Nagai, K., Sakihama, N. \& Shin, M. (1995). Four ferredoxins from Japanese radish leaves. Arch Biochem Biophys., (2): 797-802. http://dx.doi.org/10.1006/abbi.1995.1106

O'Mary, C.C., Everett, L.M. \& Graig, A.D. (1979). Production and carcass characteristics of Angus and Charolais x Angus steers. J. Anim. Sci., 48: 239.

Rigó, J. (1982). Role of food fiber in nutrition. Vopr Pitan., (4): 26-30.

Salah-Abbès, JB., Abbès, S., Abdel-Wahhab, MA. \& Oueslati, R. (2009). Raphanus sativus extract protects against ZEN-induced reproductive toxicity, oxidative stress and mutagenic alterations in male Balb/c mice. Toxicon. Jan 23.

Satoh, T., Goto, M. \& Igarashi, K. (1993). Effects of protein isolates from radish and spinach leaves on serum lipids levels in rats. J. Nutr. Sci. Vitaminol, (Tokyo). 39 (6): 627-633. 
Schaaper, WM., Posthuma, GA., Plasman, HH., Sijtsma, L., Fant, F., Borremans, FA., Thevissen, K., Broekaert, WF., Meloen, RH. \& van Amerongen, A. (2001). Synthetic peptides derived from the beta2-beta3 loop of Raphanus sativus antifungal protein 2 that mimic the active site. J. Pept. Res., 57 (5): 409-418. http://dx.doi.org/10.1034/j.1399-3011.2001.00842.x

Sipos, P., Hagymási, K., Lugasi, A., Fehér, E. \& Blázovics, A. (2002). Effects of black radish root (Raphanus sativus L. var niger) on the colon mucosa in rats fed a fat rich diet. Phytother Res., 16 (7): 677-679. http://dx.doi.org/10.1002/ptr.950

SPSS. (1998). Statistical package for Social Sciences, Chicago, U.S.A.

Zhang, X., Liu, HB., Jia, JJ. \& Lv, WH. (2010). Two novel sulfur compounds from the seeds of Raphanus sativus L. J Asian Nat Prod Res., 12 (2): 113-118. http://dx.doi.org/10.1080/10286020903479691

Table 1. Composition of the experimental diets (kg/ton)

\begin{tabular}{|l|c|c|c|c|}
\hline \multirow{2}{*}{ Item } & \multicolumn{2}{|c|}{$100 \%$} & \multicolumn{2}{c|}{$90 \%$} \\
protein requirements & protein requirements \\
\cline { 2 - 5 } & $\mathrm{G}_{1}$ & $\mathrm{G}_{2}$ & $\mathrm{G}_{3}$ & $\mathrm{G}_{4}$ \\
\hline Yellow corn & 250 & 250 & 280 & 280 \\
Barley grain & 70 & 70 & 80 & 80 \\
Wheat bran & 250 & 225 & 240 & 225 \\
Soybean meal 44\% CP & 140 & 150 & 100 & 100 \\
Alfalfa hay & 260 & 260 & 180 & 180 \\
Clover straw & ---- & ---- & 90 & 90 \\
Di-Ca-Phosphate & 10 & 10 & 10 & 10 \\
Lime stone & 10 & 10 & 10 & 10 \\
Sodium chloride & 5 & 5 & 5 & 5 \\
Vit. \& Min. mixture* & 3 & 3 & 3 & 3 \\
Anti fungal agent & 1 & 1 & 1 & 1 \\
DL-Methionine & 1 & 1 & 1 & 1 \\
Supplementations & --- & 15 & ---- & 15 \\
\hline Price, L.E/Ton & 2110 & 2219 & 1918 & 1973 \\
\hline
\end{tabular}

* Vit. \& Min. mixture: Each kilogram of Vit. \& Min. mixture contains: 2000.000 IU Vit. A, 150.000 IU Vita. D, 8.33 g Vit. E, $0.33 \mathrm{~g}$ Vit. K, $0.33 \mathrm{~g}$ Vit. $B_{1}, 1.0 \mathrm{~g}$ Vit. $B_{2}, 0.33 \mathrm{~g}$ Vit. $B_{6}, 8.33 \mathrm{~g}$ Vit. $B_{5}, 1.7 \mathrm{mg}$ Vit. $B_{12}, 3.33 \mathrm{~g}$ Pantothenic acid, $33 \mathrm{mg}$ Biotin, $0.83 \mathrm{~g}$ Folic acid, $200 \mathrm{~g}$

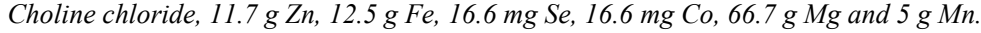

LE: Egyptians pound (local money).

Table 2. Chemical analysis and cell wall constituents of the experimental diets

\begin{tabular}{|l|c|c|c|c|}
\hline \multirow{2}{*}{ Item } & \multicolumn{2}{|c|}{$100 \%$} & \multicolumn{2}{c|}{$\begin{array}{c}9 \% \\
\text { protein requirements }\end{array}$} \\
\cline { 2 - 5 } & $\mathrm{G}_{1}$ & $\mathrm{G}_{2}$ & $\mathrm{G}_{3}$ & $\mathrm{G}_{4}$ \\
\hline Dry matter & 91.40 & 91.71 & 91.41 & 91.37 \\
\hline Chemical analysis on dry matter basis & \multicolumn{3}{|l|}{} \\
\hline Organic matter (OM) & 90.53 & 90.46 & 90.57 & 90.55 \\
Crude protein (CP) & 16.10 & 16.05 & 14.52 & 14.49 \\
Crude fiber (CF) & 11.78 & 11.10 & 11.46 & 11.80 \\
Ether extract (EE) & 3.46 & 3.44 & 3.48 & 3.56 \\
Nitrogen-free extract (NFE) & 59.19 & 59.87 & 61.11 & 60.70 \\
Ash & 9.47 & 9.54 & 9.43 & 9.45 \\
\hline Gross energy (Mcal/ kg DM) ${ }^{I}$ & 4.180 & 4.176 & 4.159 & 4.163 \\
\hline Digestible energy (kcal/kg DM) ${ }^{2}$ & 2502 & 2514 & 2518 & 2504 \\
\hline Non fibrous carbohydrates (NFC) ${ }^{3}$ & 31.55 & 32.23 & 35.24 & 35.92 \\
\hline Cell wall constituents & \multicolumn{5}{|c}{} \\
\hline NDF & 39.42 & 38.74 & 37.33 & 36.58 \\
ADF & 18.32 & 18.33 & 17.92 & 17.76 \\
ADL & 6.22 & 6.13 & 5.64 & 5.54 \\
Hemicellulose & 21.10 & 20.41 & 19.41 & 18.82 \\
Cellulose & 12.10 & 12.20 & 12.28 & 12.22 \\
\hline
\end{tabular}

${ }^{1}$ Gross energy (mega calories per kilogram DM) was calculated according to Blaxter (1968), where, each g of crude protein $(C P)=5.65$ $k c a l$, each $g$ of ether extract $(E E)=9.40 \mathrm{kcal}$, and each $\mathrm{g}$ crude fiber $(C F)$ and nitrogen-free extract $(N F E)=4.15 \mathrm{kcal}$.

${ }^{2}$ Digestible energy (DE) was calculated according to Fekete and Gippert (1986) using the following equation:

DE $(\mathrm{kcal} / \mathrm{kg} D M)=4253-32.6(C F \%)-144.4$ (total ash).

${ }^{3}$ Non fibrous carbohydrates (NFC), calculated according to Calsamiglia et al. (1995) using the following equation:

$N F C=100-\{C P+E E+A s h+N D F\}$.

NDF: Neutral detergent fiber.

ADF: Acid detergent fiber.

ADL: Acid detergent lignin.

Hemicellulose $=N D F-A D F$.

Cellulose $=A D F-A D L$. 
Table 3. Main effects of energy and supplementation levels on nutrient digestibility coefficients and nutritive values of the experimental diets

\begin{tabular}{|c|c|c|c|c|c|c|}
\hline \multirow[b]{3}{*}{ Item } & \multicolumn{5}{|c|}{ Experimental diets } & \multirow[b]{3}{*}{ SEM } \\
\hline & \multicolumn{2}{|c|}{ Protein levels } & \multirow[b]{2}{*}{ SEM } & \multicolumn{2}{|c|}{ Supplementation } & \\
\hline & $100 \%$ & $90 \%$ & & $0 \%$ & $1.5 \%$ & \\
\hline \multicolumn{7}{|l|}{ Nutrient digestibility coefficients } \\
\hline Dry matter (DM) & $71.76^{\mathrm{b}}$ & $78.54^{\mathrm{a}}$ & 1.82 & $71.24^{\mathrm{b}}$ & $79.06^{\mathrm{a}}$ & 1.82 \\
\hline Organic matter $(\mathrm{OM})$ & $62.75^{\mathrm{b}}$ & $69.90^{\mathrm{a}}$ & 1.81 & $63.26^{\mathrm{b}}$ & $69.39^{\mathrm{a}}$ & 1.81 \\
\hline Crude protein $(\mathrm{CP})$ & $72.16^{\mathrm{b}}$ & $75.32^{\mathrm{a}}$ & 1.22 & 71.42 & 76.06 & 1.22 \\
\hline Crude fiber $(\mathrm{CF})$ & $21.21^{\mathrm{b}}$ & $37.39^{\mathrm{a}}$ & 4.83 & $20.40^{\mathrm{b}}$ & $38.20^{\mathrm{a}}$ & 4.83 \\
\hline Ether extract (EE) & $77.92^{\mathrm{b}}$ & $87.33^{\mathrm{a}}$ & 2.17 & $78.04^{\mathrm{b}}$ & $87.21^{\mathrm{a}}$ & 2.17 \\
\hline Nitrogen-free extract (NFE) & 67.29 & 73.77 & 1.50 & $68.59^{\mathrm{b}}$ & $72.46^{\mathrm{a}}$ & 1.50 \\
\hline \multicolumn{7}{|l|}{ Nutritive values } \\
\hline Total digestible 1 & $60.14^{\mathrm{b}}$ & $67.15^{\mathrm{a}}$ & 1.73 & $60.68^{\mathrm{b}}$ & $66.61^{\mathrm{a}}$ & 1.73 \\
\hline Digestible crude protein (DCP) \% & $11.60^{\mathrm{a}}$ & $10.92^{\mathrm{b}}$ & 0.20 & $10.94^{\mathrm{b}}$ & $11.59^{\mathrm{a}}$ & 0.20 \\
\hline
\end{tabular}

$a$ and $b$ : Means in the same row within each treatment having different superscripts differ significantly $(P<0.05)$.

SEM, standard error of the mean.

Table 4. Effect of interactions between energy and supplementation levels on nutrient digestibility coefficients and nutritive values of the experimental diets

\begin{tabular}{|c|c|c|c|c|c|}
\hline \multirow[b]{3}{*}{ Item } & \multicolumn{5}{|c|}{ Experimental rations } \\
\hline & \multicolumn{2}{|c|}{$\begin{array}{c}100 \% \\
\text { protein requirements }\end{array}$} & \multicolumn{2}{|c|}{$\begin{array}{c}90 \% \\
\text { protein requirements } \\
\end{array}$} & \multirow[b]{2}{*}{ SEM } \\
\hline & $\mathrm{G}_{1}$ & $\mathrm{G}_{2}$ & $\mathrm{G}_{3}$ & $\mathrm{G}_{4}$ & \\
\hline \multicolumn{6}{|l|}{ Nutrient digestibility coefficients } \\
\hline Dry matter $(\mathrm{DM})$ & $70.19^{b}$ & $73.32^{b}$ & $72.28^{b}$ & $84.79^{\mathrm{a}}$ & 1.82 \\
\hline Organic matter $(\mathrm{OM})$ & $62.23^{\mathrm{b}}$ & $63.27^{\mathrm{b}}$ & $64.30^{\mathrm{b}}$ & $75.50^{\mathrm{a}}$ & 1.81 \\
\hline Crude protein $(\mathrm{CP})$ & $71.17^{\mathrm{b}}$ & $73.14^{\mathrm{ab}}$ & $71.66^{\mathrm{b}}$ & $78.98^{\mathrm{a}}$ & 1.22 \\
\hline Crude fiber $(\mathrm{CF})$ & $22.07^{\mathrm{b}}$ & $20.34^{\mathrm{b}}$ & $18.73^{\mathrm{b}}$ & $56.05^{\mathrm{a}}$ & 4.83 \\
\hline Ether extract (EE) & $72.46^{\mathrm{c}}$ & $83.39^{\mathrm{b}}$ & $83.62^{b}$ & $91.03^{\mathrm{a}}$ & 2.17 \\
\hline Nitrogen-free extract (NFE) & $67.19^{\mathrm{b}}$ & $67.38^{\mathrm{b}}$ & $69.99^{\mathrm{b}}$ & $77.54^{\mathrm{a}}$ & 1.50 \\
\hline \multicolumn{6}{|l|}{ Nutritive values } \\
\hline Total digestible nutrient (TDN)\% & $59.48^{\mathrm{b}}$ & $60.79^{\mathrm{b}}$ & $61.87^{\mathrm{b}}$ & $72.42^{\mathrm{a}}$ & 1.73 \\
\hline Digestible crude protein (DCP) \% & $11.46^{\mathrm{a}}$ & $11.74^{\mathrm{a}}$ & $10.41^{\mathrm{b}}$ & $11.44^{\mathrm{a}}$ & 0.20 \\
\hline
\end{tabular}

$a, b$ and $c$ : Means in the same row having different superscripts differ significantly $(P<0.05)$.

SEM, standard error of the mean.

Table 5. Main effects of energy and supplementation levels on growth performance of the experimental groups

\begin{tabular}{|l|c|c|c|c|c|c|}
\hline \multirow{2}{*}{ Item } & \multicolumn{5}{|c|}{ Experimental diets } & \\
\cline { 2 - 3 } & \multicolumn{2}{|c|}{ Protein levels } & & Supplementation & \\
\cline { 2 - 3 } Initial weight, g & $100 \%$ & $90 \%$ & SEM & $0 \%$ & $1.5 \%$ & SEM \\
Final weight, g & 745 & 746 & 20.62 & 743 & 748 & 20.62 \\
Total body weight gain, g & 2386 & 2432 & 50.86 & 2344 & 2474 & 50.86 \\
Duration period (days) & 1641 & 1686 & 52.59 & 1601 & 1726 & 52.59 \\
Average daily gain (ADG), g & 56 & 56 & --- & 56 & 56 & --- \\
\hline Feed intake as: & 29.30 & 30.10 & 0.94 & 28.59 & 30.82 & 0.94 \\
\hline DM, g/head/day & 77.37 & 84.08 & 1.23 & 79.07 & 82.38 & 1.23 \\
CP, g/head/day & 12.44 & 12.20 & 0.15 & 12.08 & 12.55 & 0.15 \\
DCP, g/head/day & 8.98 & 9.19 & 0.15 & $8.63^{\mathrm{b}}$ & $9.54^{\mathrm{a}}$ & 0.15 \\
TDN, g/head/day & $46.54^{\mathrm{b}}$ & $56.55^{\mathrm{a}}$ & 1.59 & $48.01^{\mathrm{b}}$ & $55.07^{\mathrm{a}}$ & 1.59 \\
DE, Kcal/head/day & 194.1 & 211.2 & 3.10 & 198.7 & 206.6 & 3.10 \\
\hline Feed conversion (g intake/g gain) of & of & \multicolumn{5}{|c}{} \\
\hline DM & $2.64^{\mathrm{a}}$ & $2.80^{\mathrm{b}}$ & 0.042 & 2.77 & 2.67 & 0.042 \\
CP & 0.42 & 0.41 & 0.006 & 0.42 & 0.41 & 0.006 \\
DCP & 0.31 & 0.31 & 0.003 & 0.30 & 0.31 & 0.003 \\
TDN & $1.59^{\mathrm{a}}$ & $1.88^{\mathrm{b}}$ & 0.039 & $1.68^{\mathrm{a}}$ & $1.78^{\mathrm{b}}$ & 0.039 \\
DE (Kcal intake/g gain) & $6.61^{\mathrm{a}}$ & $7.03^{\mathrm{b}}$ & 0.107 & 6.95 & 6.70 & 0.107 \\
\hline
\end{tabular}

$a$ and $b$ : Means in the same row within each treatment having different superscripts differ significantly $(P<0.05)$.

SEM, standard error of the mean

Dry matter (DM), Organic matter (OM), Crude protein (CP), Crude fiber (CF), Ether extract (EE), Nitrogen-free extract (NFE). Total digestible nutrient $(T D N)$ and Digestible crude protein $(D C P)$. 
Table 6. Effect of interactions between energy and supplementation levels on growth performance of the experimental groups

\begin{tabular}{|c|c|c|c|c|c|}
\hline \multirow{3}{*}{ Item } & \multicolumn{5}{|c|}{ Experimental rations } \\
\hline & \multicolumn{2}{|c|}{$\begin{array}{c}100 \% \\
\text { protein requirements }\end{array}$} & \multicolumn{2}{|c|}{$\begin{array}{c}90 \% \\
\text { protein requirements }\end{array}$} & \multirow[t]{2}{*}{ SEM } \\
\hline & $\mathrm{G}_{1}$ & $\mathrm{G}_{2}$ & $\mathrm{G}_{3}$ & $\mathrm{G}_{4}$ & \\
\hline Initial weight, $\mathrm{g}$ & 739 & 751 & 748 & 744 & 20.62 \\
\hline Final weight, $g$ & 2373 & 2400 & 2316 & 2547 & 50.86 \\
\hline Total body weight gain, $g$ & 1634 & 1649 & 1568 & 1803 & 52.59 \\
\hline Duration period (days) & 56 & 56 & 56 & 56 & --- \\
\hline Average daily gain (ADG), $g$ & 29.20 & 29.45 & 28.00 & 32.20 & 0.94 \\
\hline \multicolumn{6}{|l|}{ Feed intake as: } \\
\hline $\mathrm{DM}, \mathrm{g} / \mathrm{head} /$ day & $75.86^{\mathrm{c}}$ & $78.87^{\mathrm{bC}}$ & $82.27^{\mathrm{ab}}$ & $85.89^{\mathrm{a}}$ & 1.23 \\
\hline $\mathrm{CP}, \mathrm{g} / \mathrm{head} /$ day & 12.21 & 12.66 & 11.95 & 12.45 & 0.15 \\
\hline DCP, g/head/day & $8.69^{\mathrm{bc}}$ & $9.26^{\mathrm{ab}}$ & $8.56^{\mathrm{c}}$ & $9.83^{\mathrm{a}}$ & 0.15 \\
\hline TDN, g/head/day & $45.12^{\mathrm{c}}$ & $47.95^{\mathrm{bc}}$ & $50.90^{\mathrm{b}}$ & $62.20^{\mathrm{a}}$ & 1.59 \\
\hline DE, $\mathrm{Kcal} / \mathrm{head} /$ day & $190^{\mathrm{c}}$ & $198^{\mathrm{bc}}$ & $207^{\mathrm{ab}}$ & $215^{\mathrm{a}}$ & 3.10 \\
\hline \multicolumn{6}{|c|}{ Feed conversion (g intake /g gain) of } \\
\hline $\mathrm{DM}$ & $2.60^{\mathrm{a}}$ & $2.68^{\mathrm{a}}$ & $2.94^{b}$ & $2.67^{\mathrm{a}}$ & 0.042 \\
\hline $\mathrm{CP}$ & $0.42^{\mathrm{b}}$ & $0.43^{\mathrm{b}}$ & $0.43^{\mathrm{b}}$ & $0.39^{\mathrm{a}}$ & 0.006 \\
\hline DCP & 0.30 & 0.31 & 0.31 & 0.31 & 0.003 \\
\hline TDN & $1.55^{\mathrm{a}}$ & $1.63^{\mathrm{a}}$ & $1.82^{\mathrm{b}}$ & $1.93^{\mathrm{b}}$ & 0.039 \\
\hline DE (Kcal intake /g gain) & $6.51^{\mathrm{a}}$ & $6.72^{\mathrm{a}}$ & $7.39^{\mathrm{b}}$ & $6.68^{\mathrm{a}}$ & 0.107 \\
\hline
\end{tabular}

$a, b$ and $c$ : Means in the same row having different superscripts differ significantly $(P<0.05)$.

SEM, standard error of the mean.

Dry matter (DM), Organic matter (OM), Crude protein (CP), Crude fiber (CF), Ether extract (EE), Nitrogen-free extract (NFE). Total digestible nutrient (TDN) and Digestible crude protein (DCP).

Table 7. Main effects of energy and supplementation levels on carcass characteristics of the experimental groups

\begin{tabular}{|c|c|c|c|c|c|c|}
\hline \multirow[b]{3}{*}{ Item } & \multicolumn{5}{|c|}{ Experimental diets } & \multirow[b]{3}{*}{ SEM } \\
\hline & \multicolumn{2}{|c|}{ Protein levels } & \multirow[b]{2}{*}{ SEM } & \multicolumn{2}{|c|}{ Supplementation } & \\
\hline & $100 \%$ & $90 \%$ & & $0 \%$ & $1.5 \%$ & \\
\hline Slaughter weight (SW), g & 2405 & 2385 & 38.68 & 2354 & 2436 & 38.68 \\
\hline Inedible offal's* & 405 & 478 & 1050 & 471 & & \\
\hline $\begin{array}{l}\text { weight, g } \\
\% \text { of SW }\end{array}$ & $\begin{array}{l}495 \\
20.58\end{array}$ & $\begin{array}{c}478 \\
20.04\end{array}$ & $\begin{array}{l}10.59 \\
0.38\end{array}$ & $\begin{array}{c}471 \\
20.01\end{array}$ & $\begin{array}{c}502 \\
20.61\end{array}$ & $\begin{array}{c}10.59 \\
0.38\end{array}$ \\
\hline Digestive tract & & & & & & \\
\hline Full, g & 356 & 384 & 12.39 & 362 & 379 & 12.39 \\
\hline Empty, g & 167 & 180 & 5.81 & 170 & 174 & 5.81 \\
\hline Contents & 189 & 204 & 6.58 & 192 & 201 & 6.58 \\
\hline Empty body weight, g (EBW) & 2216 & 2181 & 38.6 & 2162 & 2235 & 38.6 \\
\hline $\begin{array}{l}\text { Edible offal's** } \\
\text { Head } \quad \text { weight, } g\end{array}$ & 129.7 & 137.3 & 3.86 & 134.7 & 132.3 & 3.86 \\
\hline$\%$ of SW & 5.41 & 5.76 & $\begin{array}{l}5.00 \\
0.15\end{array}$ & 5.74 & 5.44 & $\begin{array}{l}.00 \\
0.15\end{array}$ \\
\hline weight, g & $\begin{array}{r}76.83 \\
3.18\end{array}$ & $\begin{array}{r}69.17 \\
2.91\end{array}$ & 3.58 & $\begin{array}{l}69.33 \\
2.95\end{array}$ & $\begin{array}{r}76.67 \\
3.14\end{array}$ & 3.58 \\
\hline weight, $g$ & 6.00 & 6.83 & 0.38 & 6.33 & 6.50 & 0.38 \\
\hline$\%$ of SW & 0.25 & 0.29 & 0.01 & 0.28 & 0.27 & 0.01 \\
\hline Kidneys weight, $g$ & 18.83 & 18.83 & 0.78 & 17.33 & 20.33 & 0.78 \\
\hline$\%$ of SW & 0.79 & 0.80 & $\begin{array}{l}0.03 \\
0.54\end{array}$ & 0.75 & 0.84 & 0.03 \\
\hline $\begin{array}{l}\text { weight, } \mathrm{g} \\
\% \text { of SW }\end{array}$ & $0.34^{\mathrm{b}}$ & $0.38^{\mathrm{a}}$ & $\begin{array}{l}0.34 \\
0.02\end{array}$ & $\begin{array}{l}8.00 \\
0.34\end{array}$ & 0.37 & 0.02 \\
\hline Total edible offal's & 2395 & 2420 & 5.90 & 2365 & 2450 & 590 \\
\hline$\%$ of SW & 9.97 & 10.14 & 0.14 & 10.05 & 10.05 & 0.14 \\
\hline Carcass weight $\left(\mathrm{CW}_{1}\right), \mathrm{g}$ & 1425 & 1386 & 33.09 & 1387 & 1423 & 33.09 \\
\hline Carcass weight including edible offal's $\left(\mathrm{CW}_{2}\right)$ & & & & & & \\
\hline $\begin{array}{l}\text { Dressing percentages }(D P) \% \\
\mathrm{DP}_{1}\left(\mathrm{CW}_{1} / \mathrm{SW}\right)\end{array}$ & 1664 & 1626 & 38.47 & 16.22 & 1668 & 38.47 \\
\hline $\mathrm{DP}^{2}\left(\mathrm{CW}_{1} / \mathrm{EBW}\right)$ & 59.26 & 58.05 & 0.65 & 58.88 & 58.42 & 0.65 \\
\hline $\mathrm{DP}^{3}\left(\mathrm{CW}_{2} / \mathrm{EBW}\right)$ & 64.31 & 63.48 & 0.54 & 64.11 & 63.68 & 0.54 \\
\hline & 75.10 & 74.52 & 0.61 & 75.00 & 74.62 & 0.61 \\
\hline Carcass cuts & & & & & & \\
\hline For & 425.0 & 413.0 & 9.80 & 413.3 & 424.1 & 9.80 \\
\hline Middle pa & 450.2 & 438.0 & 10.42 & 438 & 450.0 & 10.42 \\
\hline Hind part, $g$ & 550.2 & 535.0 & 12.86 & 535.3 & 550.0 & 12.86 \\
\hline Chemical analysis of the 9,10 and $11^{m}$ ribs & & & & & & \\
\hline Dry matter (DM) & 34.97 & 36.58 & 0.48 & 35.17 & 36.37 & 0.48 \\
\hline $\begin{array}{l}\text { Crude protein (CP) } \\
\text { Cruder }\end{array}$ & 53.72 & 55.77 & 1.66 & & 55.43 & 1.66 \\
\hline Ether extract (EE) & 37.63 & 35.97 & 1.70 & 37.55 & 36.05 & 1.70 \\
\hline Ash & 8.65 & 8.26 & 0.15 & 8.39 & 8.52 & 0.15 \\
\hline
\end{tabular}

$a$ and $b$ : Means in the same row within each treatment having different superscripts differ significantly $(P<0.05)$.

SEM, standard error of the mean.

* In edible offal's: included fur, ears, legs and blood.

**Edible offal's: included head, liver, heart, kidneys and testes.

Empty body weight $(E B W)=$ slaughter weight - digestive tract contents. 
Table 8. Effect of interactions between energy and supplementation levels on carcass characteristics of the experimental groups

\begin{tabular}{|c|c|c|c|c|c|}
\hline \multirow{3}{*}{ Item } & \multicolumn{5}{|c|}{ Experimental rations } \\
\hline & \multicolumn{2}{|c|}{$\begin{array}{c}100 \% \\
\text { protein requirements }\end{array}$} & \multicolumn{2}{|c|}{$\begin{array}{c}90 \% \\
\text { protein requirements }\end{array}$} & \multirow[t]{2}{*}{ SEM } \\
\hline & $\mathrm{G}_{1}$ & $\mathrm{G}_{2}$ & $\mathrm{G}_{3}$ & $\mathrm{G}_{4}$ & \\
\hline $\begin{array}{l}\text { Slaughter weight (SW), g } \\
\text { Inedible offal's* }\end{array}$ & 2400 & 2410 & 2308 & 2463 & 38.68 \\
\hline weight, $g$ & 479 & 511 & 463 & 493 & 10.59 \\
\hline$\%$ of SW & 19.96 & 21.20 & 20.06 & 20.02 & 0.38 \\
\hline \multicolumn{6}{|l|}{ Digestive tract } \\
\hline Full, g & $320^{\mathrm{b}}$ & $393^{\mathrm{a}}$ & $403^{\mathrm{a}}$ & $366^{\mathrm{ab}}$ & 12.39 \\
\hline Empty, g & $150^{\mathrm{b}}$ & $184^{\mathrm{a}}$ & $189^{\mathrm{a}}$ & $172^{\mathrm{ab}}$ & 5.81 \\
\hline Contents & $170^{\mathrm{b}}$ & $209^{\mathrm{a}}$ & $214^{\mathrm{a}}$ & $194^{\mathrm{ab}}$ & 6.58 \\
\hline Empty body weight, g (EBW) & 2230 & 2201 & 2094 & 2269 & 38.6 \\
\hline \multicolumn{6}{|l|}{ Edible offal's** } \\
\hline Head & $142^{\mathrm{a}}$ & $118^{\mathrm{b}}$ & $128^{\mathrm{b}}$ & $147^{\mathrm{a}}$ & 3.86 \\
\hline$\%$ of SW & $5.92^{\mathrm{a}}$ & $4.90^{\mathrm{b}}$ & $5.55^{\mathrm{a}}$ & $5.97^{\mathrm{a}}$ & 0.15 \\
\hline weight, $g$ & 73.00 & 80.00 & 66.00 & 73.00 & 3.58 \\
\hline$\%$ of SW & 3.04 & 3.32 & 2.86 & 2.96 & 0.11 \\
\hline \multirow[t]{2}{*}{ weight, $g$} & 6.00 & 6.00 & 7.00 & 7.00 & 0.38 \\
\hline & 0.25 & 0.25 & 0.30 & 0.28 & 0.01 \\
\hline \multirow[t]{2}{*}{ Kidneys } & 17.00 & 21.00 & 18.00 & 20.00 & 0.78 \\
\hline & 0.71 & 0.87 & 0.78 & 0.81 & 0.03 \\
\hline \multirow{2}{*}{$\begin{array}{cc}\text { Testes } & \text { weight, } g \\
& \% \text { of SW }\end{array}$} & $9.00^{\mathrm{b}}$ & $7.00^{\mathrm{c}}$ & $7.00^{\mathrm{c}}$ & $11.00^{\mathrm{a}}$ & 0.54 \\
\hline & $0.38^{\mathrm{b}}$ & $0.29^{\mathrm{c}}$ & $0.30^{\mathrm{c}}$ & $0.45^{\mathrm{a}}$ & 0.02 \\
\hline \multicolumn{6}{|l|}{ Total edible offal's } \\
\hline $\begin{array}{l}\text { weight, } g \\
\% \text { of SW }\end{array}$ & $\begin{array}{c}247 \\
10.30^{\mathrm{ab}}\end{array}$ & $\begin{array}{l}232 \\
9.63^{\mathrm{b}}\end{array}$ & $\begin{array}{c}226 \\
9.79^{\mathrm{ab}}\end{array}$ & $\begin{array}{c}258 \\
10.47^{\mathrm{a}}\end{array}$ & $\begin{array}{l}5.90 \\
0.14\end{array}$ \\
\hline Carcass weight including edible offal's $\left(\mathrm{CW}_{2}\right)$ & 1460 & 1390 & 1314 & 1457 & 33.09 \\
\hline $\begin{array}{l}\text { Dressing percentages }(D P) \% \\
\operatorname{DP}^{1}\left(\mathrm{CW}_{1} / \mathrm{SW}\right)\end{array}$ & 1707 & 1621 & 1538 & 1715 & 38.47 \\
\hline $\mathrm{DP}^{2}\left(\mathrm{CW}_{1} / \mathrm{EBW}\right)$ & $60.83^{\mathrm{a}}$ & $57.68^{\mathrm{ab}}$ & $56.93^{\mathrm{b}}$ & $59.16^{\mathrm{ab}}$ & 0.65 \\
\hline \multirow[t]{2}{*}{$\mathrm{DP}^{3}\left(\mathrm{CW}_{2} / \mathrm{EBW}\right)$} & 65.47 & 63.15 & 62.75 & 64.21 & 0.54 \\
\hline & 76.55 & 73.65 & 73.45 & 75.58 & 0.61 \\
\hline \multicolumn{6}{|l|}{ Carcass cuts } \\
\hline Fore part, $g$ & 435 & 414 & 392 & 434 & 9.80 \\
\hline Middle part, $g$ & 461 & 439 & 415 & 460 & 10.42 \\
\hline Hind part, $g$ & 564 & 537 & 507 & 563 & 12.86 \\
\hline \multicolumn{6}{|l|}{ Chemical analysis of the 9,10 and $11^{\text {th }}$ ribs } \\
\hline $\begin{array}{l}\text { Dry matter (DM) } \\
\text { Chemical analysis on DM basis }\end{array}$ & $34.69^{b}$ & $35.24^{\mathrm{ab}}$ & $35.65^{\mathrm{ab}}$ & $37.51^{\mathrm{a}}$ & 0.48 \\
\hline Crude protein $(\mathrm{CP})$ & 52.58 & 54.86 & 55.54 & 55.99 & 1.66 \\
\hline Ether extract (EE) & 38.64 & 36.62 & 36.46 & 35.49 & 1.70 \\
\hline Ash & 8.78 & 8.52 & 8.00 & 8.52 & 0.15 \\
\hline
\end{tabular}

$a, b$ and $c$ : Means in the same row having different superscripts differ significantly $(P<0.05)$.

SEM, standard error of the mean. * In edible offal's: included fur, ears, legs and blood.

**Edible offal's: included head, liver, heart, kidneys and testes.

Empty body weight $(E B W)=$ slaughter weight - digestive tract contents.

Table 9. Economical evaluation of the experimental groups

\begin{tabular}{|l|cc|c|c|}
\hline \multirow{2}{*}{ Item } & \multicolumn{4}{|c|}{ Experimental rations } \\
\cline { 2 - 5 } & \multicolumn{2}{|c|}{$100 \%$} & \multicolumn{2}{c|}{$90 \%$} \\
protein requirements & protein requirements \\
\cline { 2 - 5 } & $\mathrm{G}_{1}$ & $\mathrm{G}_{2}$ & $\mathrm{G}_{3}$ & $\mathrm{G}_{4}$ \\
\hline Marketing weight, Kg & 2.373 & 2.400 & 2.316 & 2.547 \\
Feed consumed as it is / rabbit, kg $^{\text {Costing of one kg feed, (LE) }}{ }^{1}$ & 4.648 & 4.816 & 5.040 & 5.264 \\
Total feed cost, (LE) $^{2.110}$ & 2.219 & 1.918 & 1.973 \\
Management/ Rabbit, (LE) $^{2}$ & 9.81 & 10.69 & 9.67 & 10.39 \\
Total cost, (LE) $^{3}$ & 4 & 4 & 4 & 4 \\
Total revenue, (LE) $^{4}$ & 28.81 & 29.69 & 28.67 & 29.39 \\
Net revenue $^{\text {Economical efficiency }}$ & 52.21 & 52.80 & 50.95 & 56.03 \\
Relative economic efficiency $^{6}$ & 23.40 & 23.11 & 22.28 & 26.64 \\
Feed cost / kg LBW (LE) $^{7}$ & 0.8122 & 0.7784 & 0.7771 & 0.9064 \\
& 100 & 95.80 & 95.70 & 111.6 \\
\hline
\end{tabular}

${ }_{2}^{1}$ Based on prices of year 2011.

Feed cost / kg LBW (LE)

2 Include medication, vaccines, sanitation and workers.

include the feed cost of experimental rabbit which was LE $15 /$ rabbit + management.

${ }^{4}$ Body weight $x$ price of one $\mathrm{kg}$ at selling which was $L E 22$.

${ }_{5}$ net revenue per unit of total cost.

${ }^{6}$ Assuming that the relative economic efficiency of control diet equal 100

${ }^{7}$ Feed cost $/ \mathrm{kg} \mathrm{LBW}=$ feed intake * price of $\mathrm{kg} /$ Live weight.

LE: Egyptians pound (local money). 